\title{
Information Literacy for Santri in Islamic Boarding School (Pesantren)
}

\author{
Nuhrodin ${ }^{1}, *$ Meiry Akmara Dhina ${ }^{2}$ \\ ${ }^{1,2}$ Universitas Al-Ghifari, Jl. Cisaranten Kulon No.140, Bandung, West Java, Indonesia \\ *meiryakmaradhina@gmail.com
}

\begin{abstract}
Information literacy is a skill needed by everyone as an anticipatory step to the speed of information as a direct influence of the development of technology and information. Information literacy is essential to create effective and efficient measures in finding, selecting and evaluating the information needed. Pesantren, one type of education in Indonesia, requires attention in terms of information literacy. The entry of technology and input into the world of pesantren encourages pesantren to apply information literacy to pesantren education. However, the success of information literacy in Islamic boarding schools must deal with the unique culture of the pesantren itself. This study describes how students' information literacy includes problems and the steps taken to improve students' literacy skills today amid the digitalization era. This study uses data collection techniques through interviews and questionnaires. The results showed that students' literacy skills in Islamic boarding schools were quite good with an average literacy ability of $80 \%$, but still had limitations in the ability to develop information technology-based information retrieval, so further research should be carried out to build information literacy skills and based on information technology in this digital era for students in Islamic boarding schools.
\end{abstract}

Literasi informasi merupakan keterampilan yang dibutuhkan oleh semua orang sebagai langkah antisipasi terhadap lajunya informasi sebagai pengaruh langsung dari perkembangan teknologi dan informasi. Literasi informasi menjadi penting dimiliki untuk menciptakan langkah yang efektif dan efisien dalam mencari, memilih dan mengevaluasi informasi yang dibutuhkan. Pesantren yang merupakan salah satu tipe Pendidikan di Indonesia memerlukan perhatian dalam hal literasi informasi ini. Masuknya tekonologi dan informasi ke dunia pesantren mendorong pesantren untuk bersiap diri dalam menerapkan literasi informasi pada pendidikan pesantren. Meski demikian, kesuksesan literasi informasi pada pendidikan pesantren harus berhadapan dengan kultur pesantren itu sendiri yang bersifat unik. Penelitian ini bertujuan untuk mendeskripsikan bagaimana literasi informasi santri termasuk problematika dan Langkah-langkah yang dilakukan agar meningkatkan kemampuan literasi santri saat ini ditengah era digitalisasi. Penelitian ini menggunakan teknik pengumpulan data melalui interview dan quisioner. Hasil penelitian menunjukkan bahwa kemampuan literasi santri di pondok pesantren sudah cukup baik dengan rata-rata kemampuan literasi pada $80 \%$, akan tetapi masih memiliki keterbatasan dalam kemampuan dalam mengembangkan pencarian informasi berbasis teknologi informasi, sehingga perlu hendaknya dilakukan penelitian lanjutan dalam rangka 
mengembangkan kemampuan literasi informasi berbasis teknologi informasi di era digital ini pada santri di pondok pesantren.

Keywords: Information Literacy, Students, Islamic Boarding Schools.

Received: November 1, 2021; Revised: November 19, 2021; Accepted: December 25, 2021

\section{INTRODUCTION}

Pesantren is a typical system of education that is presented in Indonesia (Dhofier, 1982);(Azra, Afrianty, \& Hefner, 2007);(Pohl, 2006). Typically, Pesantren is similar to a boarding school where the students are called "santri" (Bin Tahir, 2015). It is also the place where the students reside and have their schoolwork. Historically in the Islamic community, pesantren was the first-born religious education institution in Indonesia that grew and developed self-sufficiently within the community (Zakaria, 2010);(Ma'arif, 2018). It was also considered an institution with strategic roles during the nation's establishment, especially in education. Pesantren has a firm traditional community root, which enables them to become a local and original culture product of the community in Indonesia, including West Java. This has resulted from its early presence and the popularity impressions on the indiscriminative education system and accessible by any groups of society. At first, pesantren education focused on religiousbased knowledge. This type of pesantren is knowledgeable as pesantren salafi. Alongside the rapid change of education and necessity among the people, pesantren has transformed its service. Not only oriented to religious knowledge, but pesantren also enlarge its accountability towards the quality improvement of its students, preparing them for the world's upcoming challenge. Based on the data released by the Ministry of Religion of the Republic of Indonesia in 2019, Indonesia has 27.722 registered pesantren (Ministry of Religious Affairs Indonesia, 2019), where the West Java province occupies the highest number of 8623 pesantren, as seen in the picture 1 .

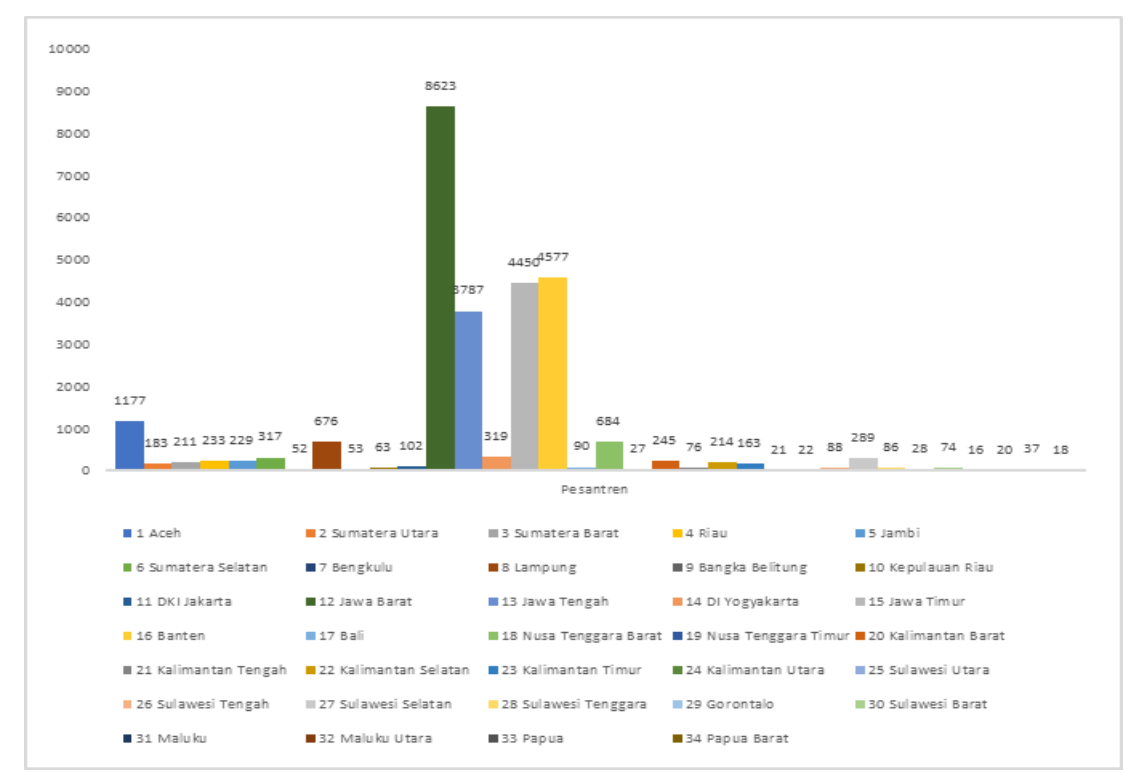

Figure 1. Graphic on the number of pesantren in each province in Indonesia(Ministry of Religious Affairs Indonesia, 2019).

Adjacent to education and Islamic learning, pesantren also play an explicit role in the community, especially in the effort and activity of community empowerment 
(Rimbawan, 2012). Pesantren carries out activities in preparing independent and skilled human resources to play an active role in development. Community empowerment activity done by pesantren is held in the form of socio-economic programs (Azzahra, 2020). So that pesantren has a significant role not only in its students but also in society.

On the other hand, the development of information and technology significantly affects and intervenes in all fields. This includes pesantren and their students. The ease of access and the abundance of information create awareness in the community that the main problem faced is how to get access to information and selectively choose the information that suits their needs. Efforts to select information turned bigger than just getting access to information (Pattah, 2014). Skills are needed in finding, selecting and retrieving correct and appropriate information. These skills are then called information literacy skills. Information literacy is the primary key in increasing students' knowledge (Muhajang \& Pangestika, 2018). With this information literacy, students will learn independently because it involves recognizing when information is needed and being efficient in searching, accurate in evaluating, effectively using, and communicating (S. Anwar, 2022). By having good information literacy, students and teachers will master their lessons in the teaching and learning process. Also, students will no longer depend on teachers because they can learn independently with their information literacy skills. This can be seen from their appearance and activities in the learning environment. Literate students will also try to learn about various information resources and be able to use these sources of information (Trahair \& Hancock, 2004);(Duriawati, Wasliman, Mulyanto, \& Barlian, 2020);(Rosmadi, 2019).

As part of the community and who will play a role in community empowerment, information literacy skills must be implemented daily. They identify the most helpful information when making decisions, for example, when searching for a business or managing a business and sharing relevant information with others (Trahair \& Hancock, 2004);(Doyle, 1994);(Breivik, 2005). The involvement of pesantren in dealing with social problems faced by the community can also be said that pesantren is not only an educational and $d a^{\prime} w a h$ institution but also an excellent role for the community from pesantren (Ridwan \& Ikhwan, 2021). The relation between pesantren as the basis of the literacy movement is that pesantren and schools are still dominated by oral culture (Dianita, 2019). The literacy culture is still complicated to implement. The Islamic intellectual tradition in pesantren is not solid from the start. This is indicated by the lack of scientific publications born from "Kiai" and Islamic boarding school scholars relative to scholars from other countries. This is thought to have something to do with the weakness of the 'literate tradition' or scientific tradition based on written reading materials in general among the public (Manshur, 2020).

The entry of literacy into the world of education in Indonesia began with the initiation of the School Literacy Movement (GLS) as a realization of the National Literacy Movement (GLN) (Handaka \& Maulana, 2017);(Nopilda \& Kristiawan, 2018). The subsequent development is the development of the Community Literacy Movement (Hidayah, 2019). All these literacy movements ultimately aim to create intelligent and critical Indonesian people in finding, reading, and selecting information. The needs of students in meeting their academic information need to support school assignments, exams and fulfilment of information in various aspects of life. The need for information arises when a person's knowledge is less than what is needed, thus encouraging someone to seek information. When someone needs information, he will 
look for the data from the many available sources (Murti \& Winoto, 2018);(Stopar \& Bartol, 2019). As part of the education sub-system that focuses on the study and discussion of Islamic religious sciences with a unique system and culture. Pesantren must also contact the rapid development of ICT. In Islamic boarding schools that openly provide access to ICT, in the end, they will come into contact with the problems of how students access information that comes in from outside into the hands of the students.

Pesantren has its uniqueness in developing the concept of information literacy because there are references to books that do not exist in other equal educational institutions (Istiqoriyah, 2019);(Zaenudin, 2019);(R. K. Anwar, Komariah, \& Rahman, 2017). The concept of information literacy is very much in line with organizing education in Islamic boarding schools. The characteristics possessed by this pesantren are potentials that can support the implementation and process of developing information knowledge. Most of the students already understand the concept of information literacy in general. The students are aware of the importance of information literacy skills for them. In general, the students were aware of their information needs. In this case, pesantren can also provide facilities to meet their needs, even modest. Thus, it is necessary to evaluate various incoming information among students to filter incoming data according to the needs and portions. The existence of obstacles related to the ability to write, present and publish various information with others through ICT still occurs (Chandra, 2020);(Rifauddin, Ariyanti, \& Pratama, 2020).

This study aims to determine the extent of students' information literacy skills in Islamic boarding schools. This research is different from other information literacy research, which generally examines the influence and development of information literacy on student learning outcomes. Namely at the boarding school located in a big city, but is more than one century old. The results of this study can then be used as a basis for efforts to develop information literacy skills at the pesantren.

\section{METHOD}

This study aims to determine the extent of students' information literacy skills in Islamic boarding schools. The research approach used to answer the research problem is descriptive qualitative as a method used to find the knowledge of the research subject at a specific time and discuss general cases of various social phenomena found. This approach also aims to describe particular things observed from the point of view of why and how to a reality that occurs both behaviours seen on the surface of social layers and hidden ones. Behind all the behaviour that occurs. We researched one of the oldest Islamic Boarding Schools in Bandung City. This boarding school was founded in $1881 \mathrm{AD}$ and has produced various alumni spread to multiple corners of the country. The objects used as research sources are the pesantren leaders, the ustadz and students (Ikhwan, 2021).

This research was conducted in several stages: a preliminary study, Focus Group Discussion (FGD), making instruments, collecting data, processing, analyzing, and concluding. Preliminary studies related to students' literacy skills in Islamic boarding schools were conducted using the interview method. The FGD was led to formulate the instrument to obtain relevant data regarding the students' literacy skills at the Islamic boarding school. 
To record the extent of students' literacy skills, we developed a questionnaire from the Tool for Real-Time Assessment of Information Literacy Skills (TRAILS) on information literacy skills (Miller, 2016). Developing the Questionnaire instrument begins with making indicators to be explored, which are students' literacy abilities. Then this questionnaire was completed as an online-based questionnaire because this research was carried out during the covid-19 pandemic so that the interaction between researchers and students in Islamic boarding schools was limited. Besides that, it also facilitated the process of collecting questionnaire data. The questionnaire results were processed using the Likert method to see the level of literacy ability based on a scale formed in weights 1 to 5 .

This data is then analyzed and integrated with data in the field, and then conclusions are drawn. The data analysis technique was carried out through the following stages (Figure 2):

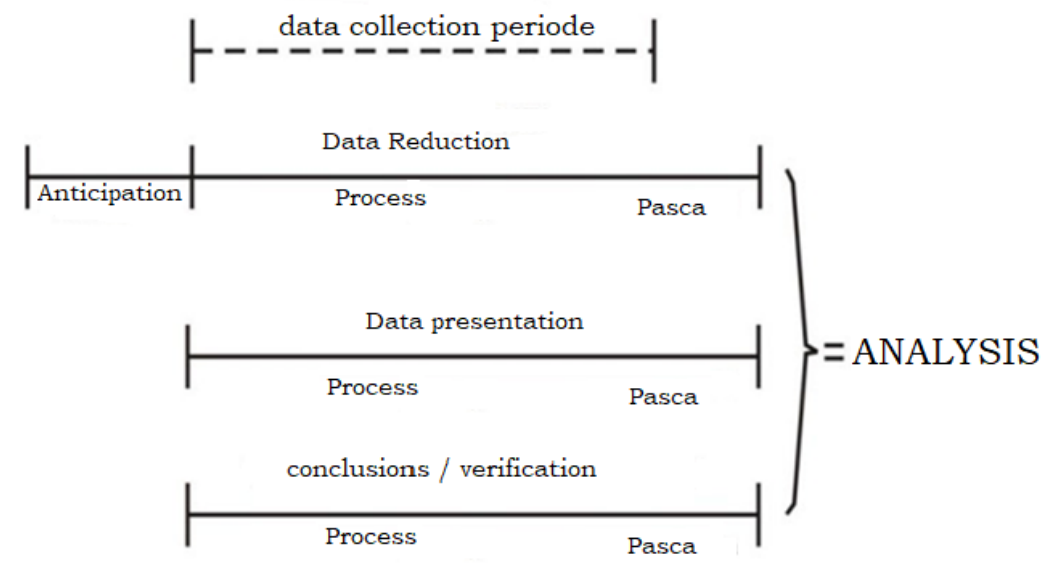

Figure 2. Data analysis stages

First, before the researchers go into the field, carry out anticipatory activities to adjust to the social situation in the field. Researchers use this ready activity by preparing a conceptual framework for the research area, research problems and selecting the approach. Second, making data reduction by removing, selecting, focusing, and making digests to obtain new categories. This activity is carried out during the data collection process and after all the required data has been collected. Third, data presentation. This process is a systematic process of presenting data to conclude. This process is carried out by displaying data in tables, flowcharts, schematics, and narratives to be easier to read and understand. They were fourth, completing by finding patterns and meanings from the data obtained. This conclusion is still tentative and requires re-verification until it can develop a proposition to form a substantive theory.

\section{RESULT AND DISCUSSION}

Students' literacy ability in Islamic boarding schools is exciting for researchers to be appointed in today's digital era. How this information literacy ability is carried out through interviews and questionnaires that have been developed. Interview questions as a preliminary study related to the condition of literacy facilities for students in Islamic boarding schools. The results showed that pesantren had provided a means to improve literacy skills. Pesantren has also facilitated improving information literacy 
skills. In line with the development of today's all-digital media, students need the ability of students to manage correct information, not to go along with it. Students can obtain information through print and electronic media; this ability is also developed by creating stimulus activities to improve information literacy through literacy competitions, "tausiyah" competitions and essay writing competitions held every year. However, these activities have not been used as evaluation materials for their literacy skills.

\section{Research Instrument Development}

The results of the development of the TRAILS instrument to record the extent to which students' literacy skills consist of topic development, identification of sources of information, development of search strategies, evaluation of information, and ethical use of data. These things are used as indicators developed in the form of questions or questionnaire statements. This questionnaire is then made in a digital version using a google form to obtain data efficiently and respond to restrictions related to the Covid19 pandemic.

The development of questions and statements that refer to the indicator of topic development is produced as follows: 1) I always make some questions about the theme that I will write to know what I should write. 2) I always use the question "how" to ask how or the process of doing something. 3) I always have trouble developing a particular theme or topic into an essay or a text.

In the indicator "Identification of sources of information", the ability to recognize information needs, which is derived in the form of a statement that must be responded to by students, namely "I can always determine the theme I will write for myself if the teacher does not determine a particular theme in writing". The ability to identify a variety of potential sources of information is derived from the two statements "I always read various sources of information found in libraries such as dictionaries, encyclopedias, magazines and newspapers" and "I always avoid information on the internet because it is not useful for growing knowledge".

The indicator of the ability of search strategy development, which serves to read how the ability to develop and use good strategies to find information, is revealed to be the following statements: 1) I always use card catalogues to make it easy to find the book I want in the library. 2) I never search for information through a google search engine. 3) I never look at the table of contents when reading a book.

The ability to "evaluate information" is developed into several sub-indicators. 1) The ability to choose appropriate information for the problem or question, the ability to choose information according to the problem or question, the statement "I can always formulate questions (what, who, where, how, why and when) when I get the task of summarizing the text" and "I always can distinguish between fact and opinion. For example, "Jokowi is the president of Indonesia", the statement is a fact". The two statements must be responded to by students who explore whether students can evaluate the information they receive. 2) Ability to apply information to critical thinking and problem-solving. The statement "I can always use punctuation marks such as periods (.), commas (,), quotes ("), question marks (?), command punctuation marks (!) and capital letters correctly.

The statement reads the extent to which students understand the information they read through information media by following the rules of writing that impact the meaning 
of information. The next statement, "I always have difficulty giving opinions on the problems discussed in writing text activities", this question explores critical thinking and problem-solving skills and finally, the statement "I ignore the rules of the structure of writing a text in text writing activities" This statement explores the extent to which students can pour information from the literacy obtained so that it can be translated by people who read it correctly without any different perceptions. 3) Ability to design, develop and evaluate information products and solutions related to personal interests, derived from the statement "I can always find the information I need from various information sources such as the internet and books in the library". "I'm always lazy to improve my writing if there is an error in the activity of writing a text". "I always re-read what I wrote when I finished writing because I wanted to improve my writing." 4) The ability to develop strategies to revise, develop and update students' knowledge, this ability is reduced to the statements "I always read the newspaper or watch the news on TV to find the latest news about everyday events in human life" and "I am always not interested in looking for various information although looking for various information can increase knowledge. The statement reads how the ability of students to develop understanding from the results of information literacy.

The ethical use of information indicators is derived into two sub-indicators: 1) The ability to use information technology responsibly, which is revealed in the statement, "I do not plagiarize the writings of others from the internet, or certain books then admit it as my writing". "I always don't understand how to use the library independently and behave properly in the library." And "I always use the internet for fun such as playing games, searching for favourite songs and opening Facebook". 2) The ability to share knowledge and information with others is revealed in two statements, namely, "I always read and discuss with friends to exchange opinions and exchange information". And "I never share information and discuss with friends or other people".

\section{Results of data processing and discussion}

Theoretically, information literate people will have confidence, independence, full of initiative, and high motivation to carry out various activities. In addition, the student is an individual who knows how to learn and continues to make efforts to carry out lifelong learning, which is the primary mission of implementing education (Asmadi, Ikhwan, \& Nuraini, 2021). Information literacy is a prerequisite, core, and foundation or foundation of lifelong learning. Thus, these two concepts cannot be separated from one another (Pattah, 2014). The results of the questionnaire data processing were carried out using the Likert method so that an overview of literacy skills was obtained, as shown in Figure 3. 


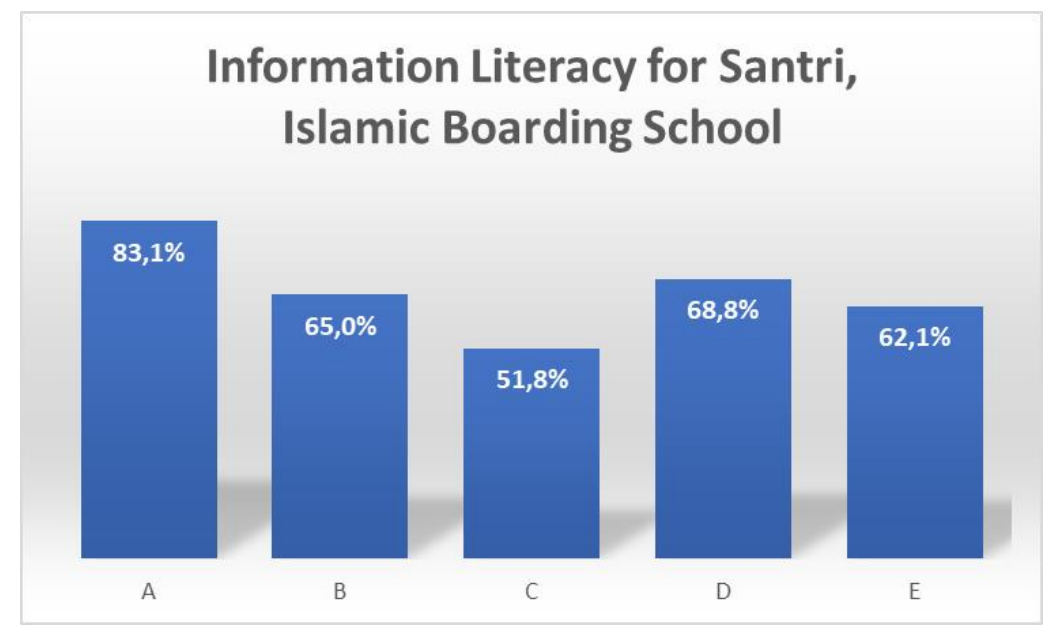

Figure 3. Information literacy level chart

Description:
a. Topic development
b. Identify sources of information
c. Search strategy development
d. Information evaluation
e. Ethical use of information

Processing of the questionnaire data in figure 3 is done by interpreting the percentage of tabulated data using the following scale:

$1 \%-20 \%$ really don't understand

$21 \%-40 \%$ do not understand

$41 \%-60 \% \quad$ average understand

$61 \%-80 \% \quad$ understand

$81 \%-100 \% \quad$ very understanding

The results of data processing literacy skills with the indicator "topic development" were obtained at $83.1 \%$, which stated that this ability was in very understanding interpretation. This Islamic boarding school, which spurs literacy skills, is outstanding in developing children's ability to build information.

Everyone needs information about their life demands, supporting activities and fulfilling their needs. A person's curiosity arises because he always wants to improve his knowledge. The need for information is a situation that occurs where a person feels there is a lack of information or knowledge as a result of a task or just curiosity. This deficiency needs to be filled with new information as required. So it is necessary to have the ability to identify sources of information (Krech, Crutchfield, \& Ballachey, 1962). The data processing results on the identification of "sources of information" obtained by $65.0 \%$. This percentage shows that the ability is in the range of understanding. So that it can also be defined, the power of students to identify the source of this information is also good.

Questions that explore the extent of literacy skills regarding students' search strategies for information. This ability is the lowest among the five indicators studied, 51.8\%. 
The development of this information search is recorded regarding the ability to find information using online media. It appears that the ability to seek information from students needs to be developed online. The development of information literacy based on digital information systems needs to be designed to increase the ability to search for information among students and Islamic boarding schools.

Overall, the ability to evaluate information is $68.8 \%$, stating that students understand how to evaluate information sources. This is in distinguishing which information is fact and which is an opinion, as well as in formulating questions regarding the data obtained and using appropriate punctuation in sentences that describe students understanding of the sentences of information received.

The ability to use ethical information as a complete result from data processing at a percentage of $62.1 \%$, which illustrates that students can use information technology responsibly, use information media according to their functions, and display that students can share knowledge and information with others.

\section{CONCLUSION}

Skills of students in Islamic boarding schools. This research is different from other information literacy research, which generally examines the influence and development of information literacy on student learning outcomes. Namely at the boarding school located in a big city, but is more than one century old. The results of this study can then be used as a basis for efforts to develop information literacy skills at the pesantren. The level of information literacy skills of Islamic boarding school students is quite good, but what needs to be developed from the literacy skills is developing information-seeking strategies so that the development of information literacy skills based on digital information systems needs to be developed further.

\section{ACKNOWLEDGEMENTS}

This research is being conducted and was supported by RISTEK-BRIN and research institutions and community service of Universitas Al-Ghifari, Thank you for the help of RISTEK-BRIN.

\section{REFERENCES}

[1] Anwar, R. K., Komariah, N., \& Rahman, M. T. (2017). Pengembangan Konsep Literasi Informasi Santri: Kajian di Pesantren Arafah Cililin Bandung Barat. Wawasan: Jurnal Ilmiah Agama Dan Sosial Budaya, 2(1), 131-142.

[2] Anwar, S. (2022). Evaluasi Pendidikan Menuju Insan Kamil Perspektif Filsafat Islam. JURNAL PENDIDIKAN NUSANTARA, 1(1), 62-76.

[3] Asmadi, Ikhwan, A., \& Nuraini. (2021). Implementasi Program Tahfidz dalam Meningkatkan Motivasi Menghafal Al-Qur'an (Studi Komparatif di Pondok Pesantren Wali Songo Ngabar Dan Pondok Pesantren Darul Fikri Bringin Ponorogo). JMP: Jurnal Mahasiswa Pascasarjana, 1(1), 1-36.

[4] Azra, A., Afrianty, D., \& Hefner, R. W. (2007). Pesantren and madrasa: Muslim schools and national ideals in Indonesia. Schooling Islam: The Culture and Politics 
of Modern Muslim Education, 172-198.

[5] Azzahra, N. F. (2020). Effects of the Pesantren Law on Indonesia's Education System - A Projection. Center for Indonesia Policy Studies, (9), 1-32.

[6] Bin Tahir, S. Z. (2015). The attitude of Santri and Ustadz toward multilingual education at Pesantren. International Journal of Language and Linguistics, 3(4), 210-216.

[7] Breivik, P. S. (2005). 21st century learning and information literacy. Change: The Magazine of Higher Learning, 37(2), 21-27.

[8] Chandra, P. (2020). Peran Pondok Pesantren Dalam Membentuk Karakter Bangsa Santri Di Era Disrupsi. Belajea: Jurnal Pendidikan Islam, 5(2), 243-262.

[9] Dhofier, Z. (1982). The pesantren tradition: the role of the kyai in the maintenance of traditional Islam in Java. Monograph Series Press, Program for Southeast Asian Studies, Arizona State ....

[10] Dianita, E. R. (2019). Budaya Literasi Santri (Studi Kasus di Pondok Pesantren Nurul Islam Kecamatan Antirogo Kabupaten Jember).

[11] Doyle, C. S. (1994). Information literacy in an information society: A concept for the information age. Diane Publishing.

[12] Duriawati, A. D., Wasliman, I., Mulyanto, A., \& Barlian, U. C. (2020). Implementation of Literation Based Learning Information Technology. International Journal of Nusantara Islam, 8(2), 240-253.

[13] Handaka, I. B., \& Maulana, C. (2017). Peran Guru Bimbingan Dan Konseling Dalam Implementasi Gerakan Literasi Nasional. Prosiding Seminar Bimbingan Dan Konseling, 1(1), 227-237.

[14] Hidayah, L. (2019). Revitalisasi Partisipasi Masyarakat Dalam Gerakan Literasi Nasional: Studi Pada Program Kampung Literasi. Jurnal Bidang Pendidikan Dasar, 3(1), 87-98.

[15] Ikhwan, A. (2021). Metode Penelitian Dasar (Mengenal Model Penelitian dan Sistematikanya). Tulungagung: STAI Muhammadiyah Tulungagung.

[16] Istiqoriyah, L. (2019). The Inheritance of Pesantren Tradition in Information Literacy: a Case Study in Darul Muttaqin. 2nd Internasional Conference on Culture and Language in Southeast Asia (ICCLAS 2018), 155-157. Atlantis Press.

[17] Krech, D., Crutchfield, R. S., \& Ballachey, E. L. (1962). Individual in society: A textbook of social psychology.

[18] Ma'arif, S. (2018). Education as a Foundation of Humanity: Learning from the Pedagogy of Pesantren in Indonesia. Journal of Social Studies Education Research, 9(2), 104-123.

[19] Manshur, F. (2020). Typical Literary Works of Pesantren on Righteousness Teaching within Cultural Transformation. Journal of Social Studies Education Research, 11(4), 114-148.

[20] Miller, C. (2016). TRAILS: tool for real-time assessment of information literacy skills. The Charleston Advisor, 17(3), 43-48.

[21] Ministry of Religious Affairs Indonesia. (2019). Pangkalan Data Pondok Pesantren. 
[22] Muhajang, T., \& Pangestika, M. D. (2018). Pengaruh Literasi Informasi Terhadap Efektivitas Belajar Siswa. Pedagonal: Jurnal Ilmiah Pendidikan, 2 (2), 15-22.

[23] Murti, D. P., \& Winoto, Y. (2018). Hubungan antara kemampuan literasi informasi dengan prestasi belajar siswa SMAN 1 Cibinong kabupaten Bogor. BIBLIOTIKA: Jurnal Kajian Perpustakaan Dan Informasi, 2(1), 1-5.

[24] Nopilda, L., \& Kristiawan, M. (2018). Gerakan literasi sekolah berbasis pembelajaran multiliterasi sebuah paradigma pendidikan abad ke-21. JMKSP (Jurnal Manajemen, Kepemimpinan, Dan Supervisi Pendidikan), 3(2), 216-231.

[25] Pattah, S. H. (2014). Literasi informasi: peningkatan kompetensi informasi dalam proses pembelajaran. Khizanah Al-Hikmah: Jurnal Ilmu Perpustakaan, Informasi, Dan Kearsipan, 2(2), 108-119.

[26] Pohl, F. (2006). Islamic education and civil society: Reflections on the pesantren tradition in contemporary Indonesia. Comparative Education Review, 50(3), 389409.

[27] Ridwan, Y., \& Ikhwan, A. (2021). Education of Religious Characters in Indonesia. 2nd Annual Conference on Blended Learning, Educational Technology and Innovation (ACBLETI 2020), 435-440. Atlantis Press.

[28] Rifauddin, M., Ariyanti, N. N., \& Pratama, B. A. (2020). Pembinaan literasi di pondok pesantren sebagai bekal santri hidup bermasyarakat. Info Bibliotheca: Jurnal Perpustakaan Dan Ilmu Informasi, 1(2), 99-112.

[29] Rimbawan, Y. (2012). Pesantren dan Ekonomi: Kajian Pemberdayaan Ekonomi Pesantren Darul Falah Bendo Mungal Krian Sidoarjo Jawa Timur.

[30] Rosmadi, M. L. N. (2019). Literation Information in Higher Education to Improve Student Competency. Darul 'Ulum Islamic University, 302.

[31] Stopar, K., \& Bartol, T. (2019). Digital competences, computer skills and information literacy in secondary education: mapping and visualization of trends and concepts. Scientometrics, 118(2), 479-498.

[32] Trahair, N. S., \& Hancock, G. J. (2004). Steel member strength by inelastic lateral buckling. Journal of Structural Engineering, 130(1), 64-69.

[33] Zaenudin, H. N. (2019). Information literacy for the net generation to anticipate the danger of intolerance. Jurnal Aspikom, 4(1), 83-95.

[34]Zakaria, G. A. N. (2010). Pondok pesantren: changes and its future. Journal of Islamic and Arabic Education, 2(2), 45-52. 